\title{
National socialism and the crisis of sociology
}

\author{
Andreas Kranebitter · Kenneth Horvath
}

(C) Springer Fachmedien Wiesbaden 2015

National Socialism marks a crisis of sociology in various regards. First, in the sense of a crucial phase of its socio-historical development (the experiences of exile by countless intellectuals and the more or less complete expulsion of some "schools" of sociology are only examples for the many forms in which the WWII-era has left its traces on the development of postwar sociology). Second, Nazi-reign marks a critical analytical challenge - both as a potential object of enquiry and as a starting point for reflecting our understanding of modern society. Third, National Socialism raises critical questions regarding sociology's cognitive identity, concerning, for example, fundamental epistemological problems such as the role of the historical in sociological analysis. Finally, all these aspects of crisis are related to the political dimension of what role sociology can and should play in the face of concrete societal developments.

The main objective of this special issue is to further our understanding of these connected crises and discuss their implications. To this end, we propose an analytical scheme that relates different problem dimensions that are present, but not explicit in current debates on the relation between sociology and National Socialism. Second, we aim to extend the geographic scope of a debate that has - at least in recent

\footnotetext{
A. Kranebitter $(\square)$

Institut für Soziologie,

Rooseveltplatz 2,

1090 Vienna, Austria

e-mail: andreas.kranebitter@univie.ac.at

K. Horvath

Pädagogische Hochschule Karlsruhe,

Bismarckstraße 10,

76133 Karlsruhe, Germany

e-mail: kenneth.horvath@univie.ac.at
} 
years - been suspiciously restricted to developments within the territorial boundaries of Western Germany. ${ }^{1}$

\section{Sociology and the problem of national socialism: recurrent debates}

This special issue is motivated by an ongoing debate on the relations between German sociology and National Socialism. ${ }^{2}$ Recent newspaper reviews of this debate state that post-WWII sociology has by and large neglected National Socialism as an object of enquiry as well as its own role during the years of Nazi-reign. There are good reasons and substantial evidence for this diagnosis. What is surprising about it, however, is that very similar arguments have actually been made several times over the past decades - often followed by intense, sometimes even heated debates in a "field where emotional debates are rather rare" (Lautmann 1997). Many notable sociologists of the postwar era have contributed to these debates in one form or the other. There is, in other words, a noticeable simultaneity of widespread analytical neglect and emotional debate. This simultaneity is an important feature of the debates about National Socialism in German-speaking sociology. It is also a fruitful starting point for outlining the rationale and structure of the special issue.

One of the characteristics of the recurrent debates on sociology and National Socialism is that they are structured by a number of antagonistic pairs. Is National Socialism a historic exception on the path of societal progress - or is it merely modernity's other face? Can NS-sociology be called "scientific" or was it mere "pseudo-science" (Dahrendorf 1967, p. 98)? Was there a "German Sociology” (Rammstedt 1986) or was this essentially a retrospective invention by those who had stayed (Maus 1959, p. 79)? Was NS-sociology built on an atheoretic empiricism (König 1987, p. 390; Gerhardt 1998) — or was it, on the contrary, rather a kind of pseudo philosophy or "romanticised folklore studies" (Maus 1959, p. 76; Adorno 1972)? Was it sociology at all —or rather a form of anti-sociology (Lepsius 1981, p. 19)? Is the relation between pre-/postwar sociology and its NS-variant one of continuity-or one of rupture? Have these issues, finally, been adequately and sufficiently discussed-or is there a need for more research (Deißler 2013; see also Bach 2012)?

One may argue that these dichotomisations mark false antinomies. Answers to any of these questions will depend on the level of analysis and the concrete aspects taken into account. The problem of exceptionality of National Socialism - and the implicated question of its relation to modernity-may serve as an example. The search by those sociologists who survived the Nazi concentration camps for an appropriate

\footnotetext{
${ }^{1}$ The special issue is based on a panel discussion that took place during the 2013 Austrian Congress of Sociology at the University of Linz, organized and chaired by the two editors of this volume. The general topic of this Congress was "Krisen in der Gesellschaft-Gesellschaft in der Krise". Among others, the congress CfP raised the question whether current sociology with its strong conceptual and methodological orientation towards normality was at all capable of analysing societal crises. This special issue is based on the assumption that the problem of National Socialism provides an extraordinarily important case in point.

${ }^{2}$ We cannot recall all contributions to this most recent debate here. Firstly, this was already done elsewhere (see e.g. Christ 2011; Christ and Suderland 2014). Secondly, it would necessarily mean to rather arbitrarily fix something as a starting point which wasn't and therefore tend to neglect older contributions.
} 
method to investigate previously unknown forms and scopes of violence in concentration camps implies that there is something very exceptional about the years of Nazi rule (Kranebitter 2015). But the exceptionality implied in this methodological quest is far from characterising National Socialism as a "pest, which no sociologist may lay his hands on", as pre-, while- and post-war-sociologist Leopold von Wiese put it right after the war in a speech to the first post-war German congress of sociology (Wiese 1948) - in essence, an ontological statement about the nature of both NS and modern society as well as a programmatic statement concerning the character, role, and responsibility of postwar sociology.

This tendency to dichotomise may be read as an indication that there are more profound but silenced questions at stake. In "Vive la Crise!" Bourdieu interprets the general tendency in postwar sociology to form antagonistic pairs (starting with very basic distinctions between theory and empiry, subject and object etc.) as a symptom of the social development of the discipline itself. He argues that influential academic figures "at the cost of mutual concessions, elaborated what Erving Goffman calls a working consensus designed to give sociology the appearance of a unified science finally freed from the infantile disorders of the ideological war of all against all" (Bourdieu 1988, p. 773). "This fiction of unanimity" was stabilised by false antinomies that allowed to canalise the destructive potential of deep-seating tensions. Against this background, Bourdieu emphasised the positive potential of the crisis of this order as an opportunity to crack the crusted structures of complementary oppositions.

The formation of a comparable working consensus in German sociology after WWII may have likewise allowed to establish and maintain a disciplinary identity. Seen from this angle, the false antinomies that permeate sociological debates on National Socialism can be read as indications of more fundamental political, epistemological, and methodological oppositions silenced by what Soeffner (2010) refers to as fictitious consensuses. From time to time, these tensions erupted into debates that tended to ignore the issues actually at stake.

One of the characteristics of the current debate is that it is as much a debate about those former debates as it is a discussion about National Socialism itself. We believe that what at first sight may appear as vain self-inspection is actually very important. Current German-speaking sociology is deeply marked by the decades following WWII. Dominant forms of problematisation, categories and concepts, and underlying understandings of both society and sociology have been formed during these decades. For example, the reluctance in German-speaking sociology to use the concept of racism is arguably the effect of post-war discursive formations. The mindsets that evolved during this period have important consequences. To give but one example, the analytical neglect of continuities between NS "Fremdarbeiter" programmes and postwar guestworker regimes is arguably the immediate consequence of attempts to imagine a sharp rupture between the social order of National Socialism and post-WWII German and Austrian society (Horvath 2014; Pries 2014). The postwar debates on sociology and National Socialism mirror the various forms of agency by which and the concrete conditions under which postwar sociology developed; they are hence symptomatic for the specific sociological identity that resulted from manifold and more or less silenced theoretical, methodological, epistemologi- 
cal, and political struggles - in Western Germany as well as in Austria (Fleck 1996; Reinprecht 2014).

\section{Restructuring a variety of debates: objectives of the special issue}

Inspired by Bourdieu's notion of the objectivation of objectivation, the present special issue takes the combination of neglect, emotionality, and dichotomisation as indication of more fundamental tensions; its first objective is to explicitly face the various levels involved. Loosely building on Lepenies' (1981) differentiation of cognitive, social, and historical dimensions of sociological identity, we suggest to distinguish four analytical levels that are all present in ongoing debates, but rarely made explicit:

First, the socio-historical level which arguably has been the most prominent for a long time, be it regarding biographical entanglements, the effects of exiled sociology, or the development of concrete institutions. Second, the ontological level that has been, among others, the main focus of debates about the character of National Socialism and its relation to modernity: is National Socialism "by its nature" a modern phenomenon, and in what regards is it "essentially" different from former and later liberal/capitalist nation-state societies. Closely related to this is, third, a cognitive dimension that entails a wide array of questions ranging from epistemological disputes about whether or not sociology needs to or should engage in historical research to the concepts used for analysing societal phenomena such as National Socialism. Finally, once again building on Bourdieu, one may argue that all of these levels are inherently linked to the level of politics - they are not only informed by social and political structures, but also have important political implications.

The selection of texts in this special issue relates these different problem dimensions to each other. This objective is linked to a second aim: to broaden the geographic scope of the debate, partly by discussing the example of Austria. Compared to Germany, the development of Austrian sociology during Austrofascism and National Socialism has received relatively little attention. Whereas similar accounts of German sociology are by now overwhelmingly considered "legends" (Soeffner 2010), the perception that Austrian sociology survived the Nazi-years only "in niches" (Langer 1988, p. 27) is still relatively widespread. As Austrian Exile Studies have shown over the past decades (see prominently Stadler 1987), the emigration, expulsion and extermination of Austrian sociologists has been somewhat more total and enduring than in Germany, resulting in a lack of re-migration after 1945 and a state that Christian Fleck has prominently characterised as "autochthonous provincialization" (Fleck 1996). Among others, the Austrian case hence entails perspectives for comparative analysis - a methodological approach that is not very widespread in current NS-related debates in sociology.

\section{Overview of contributions}

Biographical questions are highly salient in discussions on sociology and National Socialism. Individual life paths are a key element of any socio-historical account of 
how sociology developed. However, their analysis is linked to a number of important theoretical and methodological challenges. In her contribution, Nicole Holzhauser focuses on the problems linked to attempts to assess the degree of continuity or discontinuity of sociology before and after 1933/1945. Her re-consideration of the empirical basis of one of the first major contributions to the ongoing debate-Otthein Rammstedt's 'German Sociology' (Rammstedt 1986) - uncovers contradictions and blind spots in existing scholarly debates. Holzhauser's analysis points to the complex ways in which the socio-historical development of individual careers and institutions as well as their ex-post analysis are intimately linked to the cognitive problem dimension, e.g. to varying conceptualisations of sociology and their respective operationalisation for empirical research. Scholars of the history of sociology have repeatedly pointed out that what is considered 'sociology' from hindsight differs widely, especially when dealing with times of lacking institutionalization and academisation (e.g. Fleck 2007; Kaesler 1984; Klingemann 2009; Lepenies 1981). The same holds for other more or less implicit conceptualisations - for example of "continuity".

The analysis of biographical continuities and ruptures is not an end in itself, since these cannot be adequately understood without reference to broad social and political contexts. Roman Pfefferle's contribution examines the interplay of individual biographies, networked agency, and institutional strategies in the concrete historical context of the University of Vienna during Nazi-reign. Based on archival material, Pfefferle reconstructs the strategies and logics underlying three appointments to sociology-related professorships and examines the manifold NS-involvements of the three successful candidates: Arnold Gehlen, Gunther Ipsen, and Adolf Günther. All three newly appointed professors relied on academic networks, they profited from the specific constellation in the Austrian academic system that by the end of the 1930s had already been influenced by the rise Austrofascism, and they made use of these contexts to promote their understandings of a truly "deutsche Soziologie". Pfefferle's analysis illustrates that an intensified debate about those who "stayed in" could further our understanding of hidden continuities beyond and below obvious ruptures. That is all the more true for the case of Austrian sociology. The various individual, cognitive, and political links of Austrian post-war sociology to Austrofascism and the phase of Nazi-rule have so far received little attention (Reinprecht 2014). Pfefferle's contribution gives a flavour of how deeply Austrian sociology was entrenched in broad political contexts and developments.

Christian Fleck shifts our focus geographically and institutionally. His contribution discusses a book proposal written by Everett C. Hughes shortly after WWII, and rejected by the director of University of Chicago Press. Hughes' book proposal was based on field notes he had made during his stay as guest professor at Goethe University Frankfurt in 1948. Fleck discusses Hughes' book project in relation to his sole published article on the topic: "Good People and Dirty Work". Fleck's contribution broadens our perspective in two important regards. First, his text illustrates that the institutional contexts and biographical contingencies that have left their marks on the debate about sociology and National Socialism are far more varied than is usually imagined. Second, it points to manifold inter- and transnational interdependencies that are neglected if the discussion is restricted to German sociology and sociologists alone. The anecdotes and situations from postwar Germany, seen through an analyti- 
cal lens very much shaped by the US-American sociology of the time, provides a highly illuminating outsider-perspective on German society during and after National Socialism. Fleck's article, however, also shows that the debate about National Socialism is not only about writing, but also about the willingness to listen (Semprún 1998). Hughes' difficulties in convincing his publisher resembles the experience of many survivors of National Socialist concentration camps as well as social scientists (see, e.g., Bettelheim 1943; Neurath 2004).

The first three contributions to this special issue start their analysis from the socio-historical level. Julia Edthofer's contribution shifts our attention explicitly to the conceptual and political dimensions. Edthofer discusses the troubled relation between two notions of racism: anti-Semitism and anti-Muslim racism. The article discusses debates between the strands of academic and political debate connected to these two forms of racialisation in the German-speaking post-Nazi and post-colonial context. Current disputes about the relationship between anti-Semitism on the one hand and anti-Muslim racism on the other have to be seen in relation to the different circumstances they stem from - and to their resulting "blind spots". Whereas Austrian research on anti-Semitism was by and large restricted to prejudice studies, research on anti-Muslim racism has been strongly influenced by post-colonial theory. Edthofer argues that the epistemological, the conceptual, and the political levels of these debates cannot be adequately understood in isolation from each other. She proposes to acknowledge memory-political implications of the debates and use them as starting point for an analysis of overlaps and differences between anti-Semitic and anti-Muslim forms of racialisation.

The final contribution by Tanja Paulitz and Bianca Prietl links the fundamental ontological discussion of the relation between National Socialism and modernity to a minute empirical analysis of historical material. Building on Bauman's diagnosis of National Socialism as distinctly modern phenomenon, Paulitz and Prietl focus on the relationship of rationality and gender, especially masculinity constructions, as it materialised in the concrete professional field of German engineering. Based on a discourse analysis of professional concepts of the German engineer as Nazi-technocrat, they demonstrate how the masculinity construction of the Nazi-technocrat is based in well-established engineering traditions, and how it reworks the historically available concept of the engineer in order to establish the engineer as the assertive "leader of the nation". The empirical analysis by Paulitz and Prietl highlights ambivalences of the relationship of rationality and modernity, and thus provides an example for the potential of sociological analysis for deepening our understanding of both National Socialism and our understanding of current society. Among others, it adds to recent analyses of the modern or even post-modern character of National Socialist state practices and the "small Führer"-roles engineers played in this context (Reichardt and Seibel 2011).

We believe that the collection of texts in this special issue illustrates the value of a historical perspective for the reflexive imagination of sociological and societal futures. In the midst of one of the many debates on the relationship between sociology and National Socialism, Albrecht (1998, p. 10) stated that there was a striking simultaneity between these controversies and more general diagnoses of "crises of sociology". His diagnosis was based on the observation that the article that opened 
the debate was preceded by an article stating a general crisis of sociology. A similar pattern applies for the latest round of debate - this time the opening contribution (Christ 2011) was immediately followed by an article discussing shortcomings of established sociological concepts of crisis (Preunkert 2011). Obviously, times of crisis are a fertile ground for the discussion of past periods (Langer 1988). Following Lepenies (1981), one might turn this argument around: the "politicisation" implied in problematising our disciplinary past marks a chance rather than a crisis for the discipline.

\section{References}

Adorno, Theodor W. 1972. Soziologische Schriften I. Frankfurt a. M.: Suhrkamp.

Albrecht, Clemens. 1998. Zur soziologischen Vergangenheitsbewältigung. Soziologie. Mitteilungsblatt der Deutschen Gesellschaft für Soziologie 27 (3): 9-15.

Bach, Maurizio. 2012. "Drittes Reich" und Soziologie. Was kann die Soziologie zum Verständnis der nationalsozialistischen Führerdiktatur beitragen? Soziologie. Mitteilungsblatt der Deutschen Gesellschaft für Soziologie 41 (1): 19-27.

Bettelheim, Bruno. 1943. Individual and mass behavior in extreme situations. Journal of Abnormal and Social Psychology 38:417-452.

Bourdieu, Pierre. 1988. Vive la Crise! For Heterodoxy in Social Science. Theory and Society 17 (5): 737-787.

Christ, Michaela. 2011. Die Soziologie und das ,Dritte Reich“. Soziologie. Mitteilungsblatt der Deutschen Gesellschaft für Soziologie 40 (4): 407-431.

Christ, Michaela, and Maja Suderland, eds. 2014. Soziologie und Nationalsozialismus. Positionen, Debatten, Perspektiven. Berlin: Suhrkamp.

Dahrendorf, Ralf. 1967. Pfade aus Utopia. Arbeiten zur Theorie und Methode der Soziologie. München: Piper.

Deißler, Stefan. 2013. Geschichtslosigkeit als Gegenwartsproblem. Ein Schlaglicht auf die epistemologische Dimension der Debatte um den Ort des Nationalsozialismus in der Soziologie. Soziologie. Forum der Deutschen Gesellschaft für Soziologie 42 (2): 127-146.

Fleck, Christian. 1996. Autochthone Provinzialisierung. Universität und Wissenschaftspolitik nach dem Ende der nationalsozialistischen Herrschaft in Österreich. Österreichische Zeitschrift für Geschichtswissenschaft 7 (1): 67-92.

Fleck, Christian. 2007. Transatlantische Bereicherungen. Zur Erfindung der empirischen Sozialforschung. Frankfurt a. M.: Suhrkamp.

Gerhardt, Uta. 1998. Gab es Soziologie im Dritten Reich?. Soziologie. Mitteilungsblatt der Deutschen Gesellschaft für Soziologie 27 (1): 5-8.

Horvath, Kenneth. 2014. Die Logik der Entrechtung. Sicherheits- und Nutzendiskurse im österreichischen Migrationsregime. Göttingen: Vandenhoeck \& Ruprecht.

Kaesler, Dirk. 1984. Die frühe deutsche Soziologie 1909 bis 1934 und ihre Entstehungs-Milieus. Eine wissenschaftssoziologische Untersuchung. Opladen: Westdeutscher Verlag.

Klingemann, Carsten. 2009. Soziologie und Politik. Sozialwissenschaftliches Expertenwissen im Dritten Reich und in der frühen westdeutschen Nachkriegszeit. Wiesbaden: Verlag für Sozialwissenschaften.

König, René. 1987. Soziologie in Deutschland. Begründer/Verächter/Verfechter. München: Hanser.

Kranebitter, Andreas. 2015. Zahlen als Zeugen. Soziologische Analysen zur Häftlingsgesellschaft des KZ Mauthausen. Wien: New Academic Press.

Langer, Josef, ed. 1988. Geschichte der österreichischen Soziologie. Konstituierung, Entwicklung und europäische Bezüge. Wien: Verlag für Gesellschaftskritik.

Lautmann, Rüdiger. 1997. Hitlers willfährige Soziologen? Editorial. Soziologie. Mitteilungsblatt der Deutschen Gesellschaft für Soziologie 27 (3): 4.

Lepenies, Wolf, ed. 1981. Geschichte der Soziologie. Studien zur kognitiven, sozialen und historischen Identität einer Disziplin. Frankfurt a. M.: Suhrkamp. 
Lepsius, M. Rainer. 1981. Die Soziologie der Zwischenkriegszeit: Entwicklungstendenzen und Beurteilungskriterien. In Soziologie in Deutschland und Österreich 1918-1945, ed. M. Rainer Lepsius, 7-23 (Kölner Zeitschrift für Soziologie und Sozialpsychologie, Sonderheft 23).

Maus, Heinz. 1959. Bericht über die Soziologie in Deutschland 1933 bis 1945. Kölner Zeitschrift für Soziologie und Sozialpsychologie 11:72-99.

Neurath, Paul M. 2004. Die Gesellschaft des Terrors. Innenansichten der Konzentrationslager Dachau und Buchenwald. Frankfurt a. M.: Suhrkamp.

Preunkert, Jenny. 2011. Die Krise in der Soziologie. Soziologie. Mitteilungsblatt der Deutschen Gesellschaft für Soziologie 40 (4): 432-442.

Pries, Ludger. 2014. Migration und Nationalsozialismus - ein immer noch blinder Fleck der Soziologie? In Soziologie und Nationalsozialismus. Positionen, Debatten, Perspektiven, eds. Michaela Christ and Maja Suderland, 406-442. Berlin: Suhrkamp.

Rammstedt, Otthein. 1986. Deutsche Soziologie 1933-1945. Die Normalität einer Anpassung. Frankfurt a. M.: Suhrkamp.

Reichardt, Sven, and Wolfgang Seibel, eds. 2011. Der prekäre Staat. Herrschen und Verwalten im Nationalsozialismus. Frankfurt a. M.: Campus.

Reinprecht, Christoph. 2014. Die österreichische Soziologie und der Nationalsozialismus. Aufbruch, Verdrängung und verletzte Identität. In Soziologie und Nationalsozialismus. Positionen, Debatten, Perspektiven, eds. Michaela Christ and Maja Suderland, 237-262. Berlin: Suhrkamp.

Semprún, Jorge. 1998. Literature or Life. New York: Penguin Books.

Soeffner, Hans-Georg. 2010. Entstehung, Wirkung und Ende einer Legende. In „,... dass die offizielle Soziologie versagt hat". Zur Soziologie im Nationalsozialismus, der Geschichte ihrer Aufarbeitung und der Rolle der DGS, ed. Silke van Dyk and Alexandra Schauer, 10-13. Essen: Deutsche Gesellschaft für Soziologie.

Stadler, Friedrich, ed. 1987. Vertriebene Vernunft I. Emigration und Exil österreichischer Wissenschaft 1930-1940. Wien: Jugend und Volk.

Wiese, Leopold von. 1948. Die gegenwärtige Situation, soziologisch betrachtet. In Verhandlungen des 8. Deutschen Soziologentages vom 19.-21. September 1946 in Frankfurt am Main: Vorträge und Diskussionen in der Hauptversammlung und in den Sitzungen der Untergruppen, ed. Deutsche Gesellschaft für Soziologie (DGS), 20-40. Tübingen: Mohr Siebeck.

Andreas Kranebitter, Soziologe und Politikwissenschafter, uni:doc fellow am Institut für Soziologie der Universität und langjähriger wissenschaftlicher Mitarbeiter der KZ-Gedenkstätte Mauthausen. Zuletzt erschienen: Kranebitter, Andreas. 2015. Zahlen als Zeugen. Soziologische Analysen zur Häftlingsgesellschaft des KZ Mauthausen. Mauthausen-Studien, Band 9. Wien: new academic press; Bundesministerium für Inneres, Andreas Kranebitter (Hrsg). 2015. KZ-Gedenkstätten und die neuen Gesichter des Rechtsextremismus. Jahrbuch 2014 der KZ-Gedenkstätte Mauthausen | Mauthausen Memorial. Forschung - Dokumentation - Information. Wien: new academic press.

Kenneth Horvath, unterrichtet an der Pädagogischen Hochschule Karlsruhe qualitative und quantitative Forschungsmethoden. Seine aktuellen Forschungsschwerpunkte liegen im Bereich der Migrations- und Bildungsforschung, mit einem Schwerpunkt auf der Wechselwirkung von gesellschaftlichen Transformationenprozessen, Migrationsregimen und Bildungsungleichheiten. Zuletzt erschienen: Horvath, Kenneth 2014. Die Logik der Entrechtung. Sicherheits- und Nutzendiskurse im österreichischen Migrationsregime, Göttingen: Vandenhoeck \& Ruprecht. 